\title{
Bisphenols and Thyroid Hormone
}

\author{
Min Joo Kim ${ }^{1}$, Young Joo Park ${ }^{2}$ \\ ${ }^{1}$ Department of Internal Medicine, Seoul National University Hospital Healthcare System Gangnam Center; ${ }^{2}$ Department of \\ Internal Medicine, Seoul National University College of Medicine, Seoul, Korea
}

In recent decades, attention has been directed toward the effects of bisphenol A (BPA) on human health. BPA has estrogenic activity and is regarded as a representative endocrine disruptor. In addition, mounting evidence indicates that BPA can disrupt thyroid hormone and its action. This review examined human epidemiological studies to investigate the association between BPA exposure and thyroid hormone levels, and analyzed in vivo and in vitro experiments to identify the causal relationship and its mechanism of action. BPA is involved in thyroid hormone action not only as a thyroid hormone receptor antagonist, but also through several other mechanisms. Since the use of bisphenols other than BPA has recently increased, we also reviewed the effects of other bisphenols on thyroid hormone action.

Keywords: Bisphenol A; Endocrine disruptors; Thyroid hormones; Receptors, thyroid hormone

\section{INTRODUCTION}

Bisphenol A (BPA, 4,4'-isopropylidenediphenol) is used to manufacture polycarbonate plastic and epoxy resins. BPA is widely used in a variety of applications, including baby bottles, food can lining, food packaging, and dental sealants [1]. Ingestion of BPA-containing food is thought to be the primary source of human exposure. BPA is a high-production-volume chemical, and the estimated production of BPA in the United States was approximately 1 million tons in 2004 [2]. As a result, human exposure to BPA is very extensive [3]. BPA is a well-known endocrine-disrupting chemical, and its estrogenic activity was documented in the early stages of its use (1960s). Considering its widespread use and potential harmful effects on human health, especially on reproduction, the use of BPA has been regulated. The United States Environmental Protection Agency has established a reference dose of $50 \mu \mathrm{g} / \mathrm{kg} /$ day and the European Food Safety Authority has set a temporary tolerable daily intake

Received: 15 November 2019, Revised: 18 November 2019,

Accepted: 26 November 2019

Corresponding author: Young Joo Park

Department of Internal Medicine, Seoul National University College of

Medicine, 101 Daehak-ro, Jongno-gu, Seoul 03080, Korea

Tel: +82-2-2072-4183, Fax: +82-2-7642-2199, E-mail: yjparkmd@snu.ac.kr of $4 \mu \mathrm{g} / \mathrm{kg} /$ day [4]. In particular, BPA has been banned from baby bottles in many countries. As concerns about public health and regulations limiting BPA use have increased, the use of other bisphenols as BPA substitutes has become more widespread.

Recently, studies on BPA have increased exponentially, revealing that BPA has other endocrine-disrupting properties in addition to its estrogenic activity. This review focuses on the thyroid-disrupting effects of bisphenols, including BPA.

\section{BPA AND THYROID FUNCTION}

Thyroid hormone is essential for development, growth, and metabolism, and plays an especially important role in neurodevelopment. Therefore, alterations of thyroid hormone function can interfere with these vital functions. Thyroid hormones, such as thyroxine $\left(\mathrm{T}_{4}\right)$, triiodothyronine $\left(\mathrm{T}_{3}\right)$, and thyroid-stimulating hormone (TSH), can be easily measured in the blood. First, we reviewed the published literature on the association between

Copyright () 2019 Korean Endocrine Society

This is an Open Access article distributed under the terms of the Creative Commons Attribution Non-Commercial License (http://creativecommons.org/ licenses/by-nc/4.0/) which permits unrestricted non-commercial use, distribution, and reproduction in any medium, provided the original work is properly cited. 
BPA exposure and thyroid hormone.

\section{Thyroid hormone in humans}

BPA exposure in humans can be evaluated by measuring urinary BPA concentrations. Previous research has demonstrated that BPA is detected in most members of the population [3], and BPA exposure has been found to be associated with thyroid hormone levels [5-8]. Several large-scale epidemiological crosssectional studies have been conducted (Table 1). Urinary BPA concentrations were negatively associated with total $\mathrm{T}_{4}$ in the United States National Health and Nutrition Examination Survey (NHANES) 2007 to 2008 [5]. Urinary BPA concentrations were negatively correlated with TSH levels in Korean National Environmental Health Survey 2012 to 2014 [6]. Serum BPA concentrations had a negative correlation with free $\mathrm{T}_{4}$ in men in the Thai National Health Examination Survey (NHES) 2009 [7]. Urinary BPA concentrations were related to increased free $T_{3}$ and decreased TSH levels in Chinese adults [8]. Small-scale studies have also shown an association between BPA and TSH [9-11]. The leading cause of thyroid dysfunction is autoimmune disease, and the Thai NHES reported that serum BPA concentrations were positively associated with thyroid peroxidase (TPO) antibody positivity [12]. These findings suggest that BPA can induce thyroid autoimmunity, resulting in thyroid dysfunction. However, in the study conducted in China, there was no association between urinary BPA concentrations and thyroid autoantibodies [8].

In pregnant women, BPA exposure can affect thyroid hormone levels [13-16]. Because thyroid hormone plays a pivotal role in fetal neurodevelopment, maternal BPA exposure has a greater clinical significance than exposure in the general population. BPA exposure during pregnancy can affect thyroid hormone levels in newborns (Table 2). A prospective pregnancy and birth cohort study in the United States, reported that urinary BPA concentrations in pregnant women were inversely correlated with TSH levels in boys [16]. Another prospective study also showed an inverse association between maternal urinary BPA concentrations and TSH in girls [17]. Even after birth, maternal BPA exposure can affect children's thyroid hormone levels through breastfeeding [18]. However, some cross-sectional studies found no association between BPA exposure and thyroid hormone in cord blood samples [19-21].

Human studies have some limitations. First, a single measurement of BPA in a spot urine sample may not be representative of overall BPA exposure. Because BPA has a short half-life, it leaves the body rapidly and does not bioaccumulate [22]. To as-

Table 1. Previous Studies of BPA Exposure and Thyroid Measures in the General Population

\begin{tabular}{|c|c|c|c|c|c|c|c|}
\hline Study & Country & Population & No. & Specimen & $\begin{array}{l}\text { BPA concentration, } \\
\mathrm{ng} / \mathrm{mL}\end{array}$ & Thyroid measures & Association \\
\hline Meeker et al. (2011) [5] & USA & Aged $\geq 20 \mathrm{yr}$ & 1,346 & Urine & $\begin{array}{l}\text { GM } 2.5 \\
\quad(95 \% \text { CI, 2.3-2.7) }\end{array}$ & $\begin{array}{l}\text { Total/free } \mathrm{T}_{4} \text {, total/ } \\
\text { free } \mathrm{T}_{3}, \mathrm{TSH}\end{array}$ & Total $\mathrm{T}_{4} \downarrow$ \\
\hline Park et al. (2017) [6] & Korea & Aged $\geq 20 \mathrm{yr}$ & 6,003 & Urine & $\begin{array}{l}\text { GM } 1.13 \\
\quad(95 \% \text { CI, } 1.06-1.20)\end{array}$ & Total $\mathrm{T}_{4}$, total $\mathrm{T}_{3}, \mathrm{TSH}$ & $\mathrm{TSH} \downarrow$ \\
\hline $\begin{array}{l}\text { Sriphrapradang et al. } \\
\text { (2013) [7] }\end{array}$ & Thailand & Aged 18-94 yr & 2,340 & Serum & $\begin{array}{l}\text { Median } 0.33 \\
\quad(\min 0-\max 66.91)\end{array}$ & Free $\mathrm{T}_{4}, \mathrm{TSH}$ & Free $T_{4} \downarrow$ (men) \\
\hline Wang et al. (2013) [8] & China & Aged $\geq 40 \mathrm{yr}$ & 3,394 & Urine & $\begin{array}{l}\text { Median } 0.81 \\
\quad(\mathrm{IQR}, 0.47-1.43)\end{array}$ & Free $\mathrm{T}_{4}$, free $\mathrm{T}_{3}, \mathrm{TSH}$ & Free $\mathrm{T}_{3} \uparrow \mathrm{TSH} \downarrow$ \\
\hline Andrianou et al. (2016) [9] & $\begin{array}{l}\text { Cyprus, } \\
\text { Romania }\end{array}$ & Adult women & 212 & Urine & $\begin{array}{l}\text { Median } 2.258 \\
\quad(\mathrm{IQR}, 1,100-4,611)\end{array}$ & $\begin{array}{l}\text { Free } \mathrm{T}_{4}, \mathrm{TSH} \text {, thyroid } \\
\text { nodules }\end{array}$ & $\begin{array}{l}\mathrm{TSH} \uparrow \text {, thyroid } \\
\text { nodule } \downarrow\end{array}$ \\
\hline Geens et al. (2015) [10] & Belgium & $\begin{array}{l}\text { Case-control } \\
\text { (obese and lean) }\end{array}$ & 194 & Urine & Median 1.7 & Free $\mathrm{T}_{4}, \mathrm{TSH}$ & $\mathrm{TSH} \uparrow$ (lean) \\
\hline Meeker et al. (2010) [11] & USA & $\begin{array}{l}\text { Men (infertility } \\
\text { clinic) }\end{array}$ & 167 & Urine & $\begin{array}{l}\text { Median } 1.3 \\
\text { (IQR, 0.7-2.4) }\end{array}$ & Free $\mathrm{T}_{4}$, total $\mathrm{T}_{3}, \mathrm{TSH}$ & $\mathrm{TSH} \uparrow$ \\
\hline Zhou et al. (2017) [55] & China & Case-control & 178 & Urine & $\begin{array}{l}\text { Median } 4.18 \\
\quad(\mathrm{IQR}, 1.74-7.01)\end{array}$ & $\begin{array}{l}\text { Thyroid cancer, } \\
\text { nodular goiter }\end{array}$ & $\begin{array}{r}\text { Thyroid cancer } \uparrow, \\
\text { nodular goiter } \uparrow\end{array}$ \\
\hline Li et al. (2019) [56] & China & $\begin{array}{l}\text { Case-control, } \\
\text { women } \geq 18 \text { yr }\end{array}$ & 1,416 & Urine & $\begin{array}{l}\text { Median } 1.35 \\
\quad(\mathrm{IQR}, 0.83-2.34)\end{array}$ & Thyroid nodule & Thyroid nodule $\uparrow$ \\
\hline
\end{tabular}

BPA, bisphenol A; GM, geometric mean; CI, confidence interval; $\mathrm{T}_{4}$, thyroxine; $\mathrm{T}_{3}$, triiodothyronine; TSH, thyroid-stimulating hormone; IQR, interquartile range. 
Table 2. Previous Research on Maternal BPA Exposure and Thyroid Measures in Newborns

\begin{tabular}{|c|c|c|c|c|c|c|c|}
\hline Study & Country & $\begin{array}{c}\text { No. } \\
\text { (newborn) }\end{array}$ & BPA specimen & BPA concentration & $\begin{array}{l}\text { Thyroid } \\
\text { specimen }\end{array}$ & $\begin{array}{l}\text { Thyroid } \\
\text { measures }\end{array}$ & Association \\
\hline Chevrier et al. (2013) [16] & USA & 364 & $\begin{array}{l}\text { Maternal urine in the } \\
\text { first and second half } \\
\text { of pregnancy }\end{array}$ & $\mathrm{GM} 1.3 \mu \mathrm{g} / \mathrm{g} \mathrm{Cr}$ & $\begin{array}{l}\text { Blood spots } \\
\text { after birth }\end{array}$ & TSH & $\mathrm{TSH} \downarrow$ (boys) \\
\hline Romano et al. (2015) [17] & USA & 249 & $\begin{array}{l}\text { Maternal urine at } 26 \\
\text { weeks of gestation }\end{array}$ & $\begin{array}{l}\mathrm{GM} 2.3 \mu \mathrm{g} / \mathrm{g} \mathrm{Cr} \\
\quad(95 \% \mathrm{CI}, 2.1-2.5)\end{array}$ & Cord blood & $\begin{array}{l}\text { Total/free } \mathrm{T}_{4} \text {, total } / \\
\text { free } \mathrm{T}_{3}, \mathrm{TSH}\end{array}$ & $\mathrm{TSH} \downarrow$ (girls) \\
\hline Minatoya et al. (2017) [19] & Japan & 283 & Cord blood & $\begin{array}{l}\mathrm{GM} 0.051 \mathrm{ng} / \mathrm{mL} \\
\quad(\mathrm{IQR},<\mathrm{LOD}-0.076)\end{array}$ & Cord blood & Free $\mathrm{T}_{4}, \mathrm{TSH}$ & None \\
\hline Sanlidag et al. (2018) [20] & Cyprus & 88 & Cord blood & Mean 4.934 ng/mL & Cord blood & Free $\mathrm{T}_{4}, \mathrm{TSH}$ & None \\
\hline $\begin{array}{l}\text { Brucker-Davis et al. (2011) } \\
\text { [21] }\end{array}$ & France & 84 & Cord blood & $\begin{array}{l}\text { Median } 0.9 \mathrm{ng} / \mathrm{mL} \\
(\mathrm{IQR}, 0.2-3.3)\end{array}$ & Cord blood & $\begin{array}{l}\text { Free } \mathrm{T}_{4} \text {, free } \mathrm{T}_{3}, \\
\quad \mathrm{TSH}\end{array}$ & None \\
\hline
\end{tabular}

BPA, bisphenol A; GM, geometric mean; Cr, creatinine; TSH, thyroid-stimulating hormone; $\mathrm{CI}$, confidence interval; $\mathrm{T}_{4}$, thyroxine; $\mathrm{T}_{3}$, triiodothyronine; IQR, interquartile range; LOD, limit of detection.

sess BPA exposure properly, repeated BPA measurements are needed, but it is difficult to obtain serial BPA measurements in real-world circumstances. Second, the causal relationship between BPA exposure and thyroid hormone changes remains unclear, and is difficult to elucidate. Most of the studies were cross-sectional, and only two studies were longitudinal. Next, humans are exposed to numerous chemicals at once, and several chemicals share similar exposure sources [23], so the findings of those studies may reflect a mixed effect, rather than the effects of BPA alone, which could lead to false positive conclusions. Therefore, the association between BPA and thyroid function in humans reported in the literature is still inconclusive.

\section{Thyroid hormone in animals}

To supplement the limitations of human epidemiological studies, several animal experiments have been conducted. BPA was administered directly to animals, and thyroid hormone levels were measured. BPA exposure ( $40 \mathrm{mg} / \mathrm{kg}, 15$ days, orally) in adult rats increased $\mathrm{T}_{4}$ levels [24]. Neonatal exposure to BPA ( 2.5 to $6.2 \mathrm{mg} / \mathrm{kg}, 10$ days, subcutaneously) decreased $\mathrm{T}_{4}$ levels and increased TSH levels in adulthood [25]. Maternal exposure to BPA in rats can affect thyroid hormone in the offspring. Zoeller et al. [26] reported that maternal BPA exposure during pregnancy and lactation (1 to $50 \mathrm{mg} / \mathrm{kg}$, orally) increased $\mathrm{T}_{4}$ levels in the offspring (postnatal day [PND] 15). Xu et al. [27] reported that maternal BPA exposure induced a transient increase in $\mathrm{T}_{4}$ levels (PND 7), followed by a decrease of $\mathrm{T}_{4}$ (PND $21)$ in male offspring. However, other researchers reported that perinatal exposure to BPA $(0.0025$ to $40 \mathrm{mg} / \mathrm{kg}$, orally or subcutaneously) did not alter TSH and $\mathrm{T}_{4}$ levels in offspring [28-31].
The inconsistent results of rat experiments may be due to different doses, windows of exposure, and routes of exposure to BPA. BPA-induced thyroid hormone changes have also been observed in mice and zebrafish. BPA exposure during puberty decreased $\mathrm{T}_{4}$ levels in mice [32]. BPA exposure to zebrafish larvae increased $\mathrm{T}_{3}$ levels [33]. All these experiments indicate that BPA could affect thyroid function, but the effects might vary according to the route, dose, duration, or age at exposure.

\section{MECHANISM OF BPA}

Thyroid hormone is synthesized in the thyroid gland under the regulation of TSH released from the pituitary gland. Synthesized thyroid hormone binds to proteins and circulates in the blood. At the target organ, thyroid hormone binds to the thyroid hormone receptor (TR) and stimulates thyroid hormone signaling pathways. Subsequently, thyroid hormone is metabolized to its inactive form in the liver. We explored the ways in which these processes are disrupted by BPA (Fig. 1) by reviewing the published mechanistic studies.

\section{Thyroid hormone synthesis}

It is possible that BPA acts directly on the thyroid gland, as suggested by the finding that in humans, urinary BPA concentrations were inversely associated with thyroid volume in children [34]. In animal studies, BPA exposure, especially during pregnancy, has been found to alter thyroid gland weight or to change thyroid histology $[35,36]$.

In thyroid hormone synthesis, iodine enters thyrocytes via the sodium iodide symporter (NIS), is oxidized by TPO, and is in- 


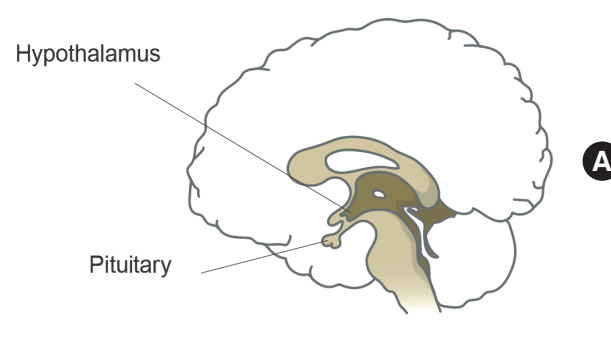

Regulation by hypothalamus and pituitary gland
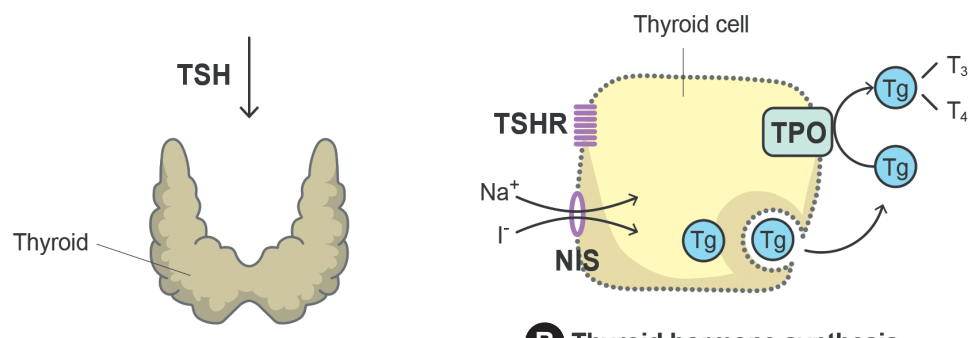

B Thyroid hormone synthesis

$\mathrm{T}_{4}, \mathrm{~T}_{3} \downarrow$

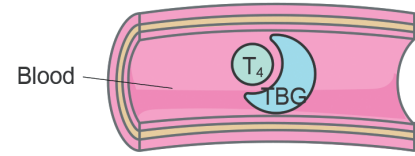

C Thyroid hormone transport

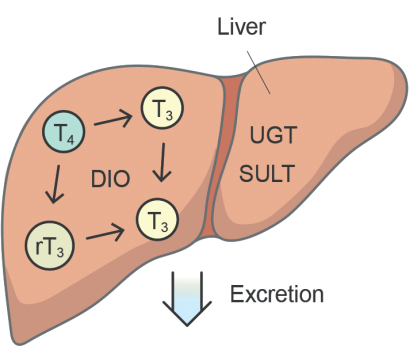

D Thyroid hormone metabolism
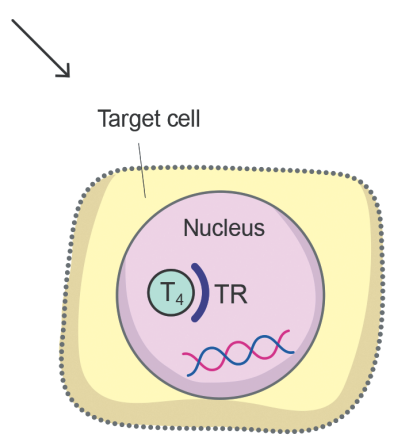

E Thyroid hormone receptor

Fig. 1. Chemicals can interfere with thyroid hormone action at several points. (A) The pituitary gland and hypothalamus regulate thyroid hormone synthesis through thyroid-stimulating hormone (TSH) release. (B) Thyroid hormone is synthesized in the thyroid gland. If TSH stimulates thyrocytes, iodine uptake via the sodium iodide symporter (NIS), thyroglobulin (Tg) production, and oxidation by thyroid peroxidase (TPO) occur. (C) Thyroid hormone is carried on binding proteins such as thyroxine-binding globulin (TBG) and transthyretin (TTR). (D) Thyroid hormone is metabolized in the liver by deiodinase (DIO), UDP-glucuronosyltransferase (UGT), or sulfotransferase (SULT) and eliminated in bile. (E) Thyroid hormone binds to the thyroid hormone receptor (TR) in target cells and activates thyroid hormone signaling pathways. $\mathrm{T}_{4}$, thyroxine; $\mathrm{T}_{3}$, triiodothyronine.

corporated into tyrosyl residues of thyroglobulin (Tg). BPA exposure has been found to change the expression of genes involved in these processes, such as Slc5a5 (NIS), Tpo, and Tg. For example, BPA treatment increased $T g$ and Slc5a5 gene expression in zebrafish experiments $[33,37,38]$ and $T s h r$, Slc5a5, $T p o$, and $T g$ gene expression in FRTL5 cells $[37,39,40]$. BPA treatment decreased iodide uptake in FRTL5 cells and TPO ac- tivity in isolated rat thyroid microsomes [40]. In rats, BPA treatment decreased thyroid iodide uptake and TPO activity [36]. These findings suggest that BPA can inhibit thyroid hormone synthesis.

\section{Regulation by the hypothalamus and pituitary gland}

Little is known about BPA-associated changes in the hypothala- 
mus and pituitary gland. BPA exposure $(0.1$ to $1 \mu \mathrm{M})$ did not change $C r h$ or $T s h \beta$ gene expression in zebrafish experiments [33]. However, BPA treatment $(10 \mu \mathrm{M})$ decreased $\operatorname{Ts} h \beta$, Tr $\alpha$, $\operatorname{Tr} \beta$, and deiodinase 2 (Dio2) expression in GH3 pituitary cells [39]. Dong and Wade [41] reported that BPA can inhibit thyroid hormone uptake via the thyroid hormone transporter monocarboxylate transporter 8 (MCT8) in the brain.

\section{Thyroid hormone transport}

In the blood, thyroid hormone is transported in conjunction with proteins such as thyroxine-binding globulin (TBG) and transthyretin (TTR). BPA can bind TTR [42]. Competitive binding with thyroid hormone transport proteins interferes with thyroid hormone. However, the affinity of BPA for TBG and TTR is weak. Instead, derivatives of BPA such as tetrachlorinate BPA (TCBPA) or tetrabrominated BPA (TBBPA) have a stronger affinity [43]. In addition, the BPA concentrations commonly found in humans are insufficient to interfere with thyroid hormone transport [42].

\section{Thyroid hormone metabolism}

Deiodination catalyzed by DIO is important in thyroid hormone metabolism. In rats, BPA treatment reduced hepatic DIO1 activity [24]. BPA exposure $(0.1$ to $1 \mu \mathrm{M})$ increased the expression of Diol gene and Ugtlab gene encoding UDP glucuronosyltrasferase in zebrafish [33].

\section{Thyroid hormone receptor}

The structure of BPA and its analogues resembles that of $\mathrm{T}_{3}$ (Fig. 2). BPA can bind TR, particularly the beta isoform of TR $(\mathrm{TR} \beta)$, and acts as an antagonist $[26,44]$, as confirmed in a cell- based reporter gene assay $[45,46]$. TR was inhibited by BPA treatment (10 to $100 \mu \mathrm{M})$, where $\mathrm{TR} \beta$ was at a lower concentration $(0.001$ to $0.1 \mu \mathrm{M})$. BPA was found to inhibit TR-mediated transcription of $\mathrm{T}_{3}$-response genes [47]. These findings suggest that BPA can disrupt the action of thyroid hormone. It is thought that the TR-antagonistic effect of BPA may be the main mechanism through which it disrupts thyroid function.

\section{OTHER BISPHENOLS AND THYROID FUNCTION}

Since concerns have been raised regarding BPA from a public health perspective, several BPA substitutes, such as bisphenol $\mathrm{F}$ (BPF) and bisphenol S (BPS), have become used with increasing frequency. Because their structures are similar to that of BPA (Fig. 2), it is possible that these bisphenols disrupt thyroid function. However, since these bisphenols are only starting to be used, little research has been conducted on their role in thyroid disruption.

Like BPA, BPF and BPS can bind TR $\beta$ and exert antagonistic activity $[48,49]$. In zebrafish, $B P F$ exposure altered $T_{4}, T_{3}$, and TSH levels and changed the expression of genes including $T g$, Ttr, and Ugt1ab [33,50].

In zebrafish, BPS exposure decreased $\mathrm{T}_{4}$ and $\mathrm{T}_{3}$ levels and increased TSH levels [51,52]. Furthermore, in zebrafish, BPS treatment increased the expression of genes including Ttr and Ugtlab [33,51].

In human, some epidemiological studies have investigated associations between non-BPA bisphenols and thyroid hormone levels, but only in pregnant women. Urinary BPF concentrations were associated with higher free $T_{3}[13]$ or free $T_{4}$ levels<smiles>N[C@@H](Cc1cc(I)c(Oc2ccc(O)c(I)c2)c(I)c1)C(=O)O</smiles><smiles>CC(C)(c1ccc(O)cc1)c1ccc(O)cc1</smiles>

A

B<smiles>Oc1ccc(Cc2ccc(O)cc2)cc1</smiles>

C<smiles>O=S(=O)(c1ccc(O)cc1)c1ccc(O)cc1</smiles>

Fig. 2. Structure of thyroid hormone and bisphenols. (A) Triiodothyronine, (B) bisphenol A, (C) bisphenol F, and (D) bisphenol S. 
[53]. Aker et al. [53] reported that urinary BPS concentrations were associated with lower corticotropin-releasing hormone levels, but other studies found no association between BPS and thyroid hormone levels [13,54].

\section{BPA AND THYROID NODULES}

As BPA became known as a thyroid-disrupting chemical, the association between BPA and thyroid nodules or thyroid cancer emerged as a topic of interest. In case-control studies conducted in China, urinary BPA concentrations in patients with thyroid nodules or thyroid cancer were significantly higher than in the control groups (Table 1) [55,56]. However, Andrianou et al. [9] reported that BPA exposure was inversely associated with thyroid nodules. In animal experiments, BPA treatment in F344 rats did not induce thyroid cancer stimulated by N-bis(2-hydroxypropyl)nitrosamine (DHPN) [57]. However, BPA treatment enhanced the susceptibility of thyroid cancer stimulated by DHPN and iodine excess in rats [58]. BPA can induce the proliferation of thyroid cancer cells [59]. Taken together, a link may possibly exist between BPA and thyroid nodules or cancer, but there is a lack of evidence that BPA can induce thyroid nodules or thyroid cancer.

\section{CONCLUSIONS}

Here, we reviewed the associations between bisphenols and thyroid function. Several previous studies indicate that BPA affects thyroid hormone action. Considering the results of studies in pregnant women and experiments on perinatal exposure, the effects of BPA on thyroid hormone are thought to be more critical and harmful in the early stages of life. BPA may affect thyroid function through several possible mechanisms of action. First, the main mechanism of action is thought to be binding of BPA to TR and interference with thyroid hormone. However, this review also suggests that BPA can interfere with thyroid hormone synthesis, transport, and metabolism. Recently, this thyroid-disrupting effect was identified for other bisphenols, as well as BPA. Although they were not the primary focus of this review, BPA derivatives such as TCBPA and TBBPA resulting from BPA degradation processes have increasingly been investigated as thyroid-disrupting chemicals [60]. Therefore, attention should be paid to the effects of bisphenols, including BPA, on the thyroid.

\section{CONFLICTS OF INTEREST}

No potential conflict of interest relevant to this article was reported.

\section{ACKNOWLEDGMENTS}

The authors would like to thank Jin Hyoung Pyo (Seoul National University Hospital Healthcare System Gangnam Center) for his assistance in drawing the figure. This research was supported by a grant (18182MFDS65) from Ministry of Food and Drug Safety in 2018.

\section{ORCID}

Min Joo Kim https://orcid.org/0000-0002-9765-9340

Young Joo Park https://orcid.org/0000-0002-3671-6364

\section{REFERENCES}

1. Kang JH, Kondo F, Katayama Y. Human exposure to bisphenol A. Toxicology 2006;226:79-89.

2. Corrales J, Kristofco LA, Steele WB, Yates BS, Breed CS, Williams ES, et al. Global assessment of bisphenol a in the environment: review and analysis of its occurrence and bioaccumulation. Dose Response 2015;13:1559325815598308.

3. Calafat AM, Ye X, Wong LY, Reidy JA, Needham LL. Exposure of the U.S. population to bisphenol A and 4-tertiary-octylphenol: 2003-2004. Environ Health Perspect 2008;116:3944.

4. Gore AC, Chappell VA, Fenton SE, Flaws JA, Nadal A, Prins GS, et al. Executive summary to EDC-2: the Endocrine Society's Second Scientific Statement on EndocrineDisrupting Chemicals. Endocr Rev 2015;36:593-602.

5. Meeker JD, Ferguson KK. Relationship between urinary phthalate and bisphenol A concentrations and serum thyroid measures in U.S. adults and adolescents from the National Health and Nutrition Examination Survey (NHANES) 2007-2008. Environ Health Perspect 2011;119:1396-402.

6. Park C, Choi W, Hwang M, Lee Y, Kim S, Yu S, et al. Associations between urinary phthalate metabolites and bisphenol A levels, and serum thyroid hormones among the Korean adult population: Korean National Environmental Health Survey (KoNEHS) 2012-2014. Sci Total Environ 2017;5845:950-7.

7. Sriphrapradang C, Chailurkit LO, Aekplakorn W, Ongphiph- 
adhanakul B. Association between bisphenol A and abnormal free thyroxine level in men. Endocrine 2013;44:441-7.

8. Wang T, Lu J, Xu M, Xu Y, Li M, Liu Y, et al. Urinary bisphenol a concentration and thyroid function in Chinese adults. Epidemiology 2013;24:295-302.

9. Andrianou XD, Gangler S, Piciu A, Charisiadis P, Zira C, Aristidou K, et al. Human exposures to bisphenol A, bisphenol $\mathrm{F}$ and chlorinated bisphenol A derivatives and thyroid function. PLoS One 2016;11:e0155237.

10. Geens T, Dirtu AC, Dirinck E, Malarvannan G, Van Gaal L, Jorens PG, et al. Daily intake of bisphenol A and triclosan and their association with anthropometric data, thyroid hormones and weight loss in overweight and obese individuals. Environ Int 2015;76:98-105.

11. Meeker JD, Calafat AM, Hauser R. Urinary bisphenol A concentrations in relation to serum thyroid and reproductive hormone levels in men from an infertility clinic. Environ Sci Technol 2010;44:1458-63.

12. Chailurkit LO, Aekplakorn W, Ongphiphadhanakul B. The association of serum bisphenol A with thyroid autoimmunity. Int J Environ Res Public Health 2016;13:E1153.

13. Derakhshan A, Shu H, Peeters RP, Kortenkamp A, Lindh $\mathrm{CH}$, Demeneix B, et al. Association of urinary bisphenols and triclosan with thyroid function during early pregnancy. Environ Int 2019;133(Pt A):105123.

14. Aung MT, Johns LE, Ferguson KK, Mukherjee B, McElrath TF, Meeker JD. Thyroid hormone parameters during pregnancy in relation to urinary bisphenol A concentrations: a repeated measures study. Environ Int 2017;104:33-40.

15. Aker AM, Watkins DJ, Johns LE, Ferguson KK, Soldin OP, Anzalota Del Toro LV, et al. Phenols and parabens in relation to reproductive and thyroid hormones in pregnant women. Environ Res 2016;151:30-7.

16. Chevrier J, Gunier RB, Bradman A, Holland NT, Calafat AM, Eskenazi B, et al. Maternal urinary bisphenol a during pregnancy and maternal and neonatal thyroid function in the CHAMACOS study. Environ Health Perspect 2013;121:13844.

17. Romano ME, Webster GM, Vuong AM, Thomas Zoeller R, Chen A, Hoofnagle AN, et al. Gestational urinary bisphenol A and maternal and newborn thyroid hormone concentrations: the HOME Study. Environ Res 2015;138:453-60.

18. Yi B, Kim C, Park M, Han Y, Park JY, Yang M. Association between endocrine disrupting phenols in colostrums and maternal and infant health. Int J Endocrinol 2013;2013:282381.

19. Minatoya M, Sasaki S, Araki A, Miyashita C, Itoh S, Yama- moto J, et al. Cord blood bisphenol a levels and reproductive and thyroid hormone levels of neonates: the Hokkaido study on environment and children's health. Epidemiology 2017;28 Suppl 1:S3-9.

20. Sanlidag B, Dalkan C, Yetkin O, Bahceciler NN. Evaluation of dose dependent maternal exposure to bisphenol a on thyroid functions in newborns. J Clin Med 2018;7:E119.

21. Brucker-Davis F, Ferrari P, Boda-Buccino M, WagnerMahler K, Pacini P, Gal J, et al. Cord blood thyroid tests in boys born with and without cryptorchidism: correlations with birth parameters and in utero xenobiotics exposure. Thyroid 2011;21:1133-41.

22. Teeguarden JG, Waechter JM Jr, Clewell HJ 3rd, Covington TR, Barton HA. Evaluation of oral and intravenous route pharmacokinetics, plasma protein binding, and uterine tissue dose metrics of bisphenol A: a physiologically based pharmacokinetic approach. Toxicol Sci 2005;85:823-38.

23. Kim S, Kim S, Won S, Choi K. Considering common sources of exposure in association studies: urinary benzophenone- 3 and DEHP metabolites are associated with altered thyroid hormone balance in the NHANES 2007-2008. Environ Int 2017;107:25-32.

24. da Silva MM, Goncalves CFL, Miranda-Alves L, Fortunato RS, Carvalho DP, Ferreira ACF. Inhibition of type 1 iodothyronine deiodinase by bisphenol A. Horm Metab Res 2019;51: 671-7.

25. Fernandez MO, Bourguignon NS, Arocena P, Rosa M, Libertun C, Lux-Lantos V. Neonatal exposure to bisphenol A alters the hypothalamic-pituitary-thyroid axis in female rats. Toxicol Lett 2018;285:81-6.

26. Zoeller RT, Bansal R, Parris C. Bisphenol-A, an environmental contaminant that acts as a thyroid hormone receptor antagonist in vitro, increases serum thyroxine, and alters $\mathrm{RC} 3 /$ neurogranin expression in the developing rat brain. Endocrinology 2005;146:607-12.

27. Xu X, Liu Y, Sadamatsu M, Tsutsumi S, Akaike M, Ushijima H, et al. Perinatal bisphenol A affects the behavior and SRC-1 expression of male pups but does not influence on the thyroid hormone receptors and its responsive gene. Neurosci Res 2007;58:149-55.

28. Sadowski RN, Park P, Neese SL, Ferguson DC, Schantz SL, Juraska JM. Effects of perinatal bisphenol A exposure during early development on radial arm maze behavior in adult male and female rats. Neurotoxicol Teratol 2014;42:17-24.

29. Bansal R, Zoeller RT. CLARITY-BPA: bisphenol A or propylthiouracil on thyroid function and effects in the developing

Copyright (C) 2019 Korean Endocrine Society 
male and female rat brain. Endocrinology 2019;160:1771-85.

30. Santos-Silva AP, de Moura EG, Pinheiro CR, Oliveira E, Lisboa PC. Short-term and long-term effects of bisphenol A (BPA) exposure during breastfeeding on the biochemical and endocrine profiles in rats. Horm Metab Res 2018;50: 491-503.

31. Kobayashi K, Miyagawa M, Wang RS, Suda M, Sekiguchi $\mathrm{S}$, Honma T. Effects of in utero and lactational exposure to bisphenol A on thyroid status in F1 rat offspring. Ind Health 2005;43:685-90.

32. Jiang W, Cao L, Wang F, Ge H, Wu PC, Li XW, et al. Accelerated reduction of serum thyroxine and hippocampal histone acetylation links to exacerbation of spatial memory impairment in aged CD-1 mice pubertally exposed to bisphenol-A. Age (Dordr) 2016;38:405-18.

33. Lee S, Kim C, Shin H, Kho Y, Choi K. Comparison of thyroid hormone disruption potentials by bisphenols $\mathrm{A}, \mathrm{S}, \mathrm{F}$, and $\mathrm{Z}$ in embryo-larval zebrafish. Chemosphere 2019;221: 115-23.

34. Wang N, Zhou Y, Fu C, Wang H, Huang P, Wang B, et al. Influence of bisphenol a on thyroid volume and structure independent of iodine in school children. PLoS One 2015;10: e0141248.

35. Ahmed RG. Maternal bisphenol A alters fetal endocrine system: thyroid adipokine dysfunction. Food Chem Toxicol 2016;95:168-74.

36. Silva MMD, Xavier LLF, Goncalves CFL, Santos-Silva AP, Paiva-Melo FD, Freitas ML, et al. Bisphenol A increases hydrogen peroxide generation by thyrocytes both in vivo and in vitro. Endocr Connect 2018;7:1196-207.

37. Gentilcore D, Porreca I, Rizzo F, Ganbaatar E, Carchia E, Mallardo M, et al. Bisphenol A interferes with thyroid specific gene expression. Toxicology 2013;304:21-31.

38. Berto-Junior C, Santos-Silva AP, Ferreira ACF, Graceli JB, de Carvalho DP, Soares P, et al. Unraveling molecular targets of bisphenol A and $\mathrm{S}$ in the thyroid gland. Environ Sci Pollut Res Int 2018;25:26916-26.

39. Lee S, Kim C, Youn H, Choi K. Thyroid hormone disrupting potentials of bisphenol $\mathrm{A}$ and its analogues: in vitro comparison study employing rat pituitary (GH3) and thyroid follicular (FRTL-5) cells. Toxicol In Vitro 2017;40:297-304.

40. Wu Y, Beland FA, Fang JL. Effect of triclosan, triclocarban, 2,2',4,4'-tetrabromodiphenyl ether, and bisphenol A on the iodide uptake, thyroid peroxidase activity, and expression of genes involved in thyroid hormone synthesis. Toxicol In Vitro 2016;32:310-9.
41. Dong H, Wade MG. Application of a nonradioactive assay for high throughput screening for inhibition of thyroid hormone uptake via the transmembrane transporter MCT8. Toxicol In Vitro 2017;40:234-42.

42. Cao J, Guo LH, Wan B, Wei Y. In vitro fluorescence displacement investigation of thyroxine transport disruption by bisphenol A. J Environ Sci (China) 2011;23:315-21.

43. Marchesini GR, Meimaridou A, Haasnoot W, Meulenberg E, Albertus F, Mizuguchi M, et al. Biosensor discovery of thyroxine transport disrupting chemicals. Toxicol Appl Pharmacol 2008;232:150-60.

44. Moriyama K, Tagami T, Akamizu T, Usui T, Saijo M, Kanamoto N, et al. Thyroid hormone action is disrupted by bisphenol A as an antagonist. J Clin Endocrinol Metab 2002; 87:5185-90.

45. Freitas J, Cano P, Craig-Veit C, Goodson ML, Furlow JD, Murk AJ. Detection of thyroid hormone receptor disruptors by a novel stable in vitro reporter gene assay. Toxicol In Vitro 2011;25:257-66.

46. Sheng ZG, Tang Y, Liu YX, Yuan Y, Zhao BQ, Chao XJ, et al. Low concentrations of bisphenol a suppress thyroid hormone receptor transcription through a nongenomic mechanism. Toxicol Appl Pharmacol 2012;259:133-42.

47. Heimeier RA, Das B, Buchholz DR, Shi YB. The xenoestrogen bisphenol A inhibits postembryonic vertebrate development by antagonizing gene regulation by thyroid hormone. Endocrinology 2009;150:2964-73.

48. Lu L, Zhan T, Ma M, Xu C, Wang J, Zhang C, et al. Thyroid disruption by bisphenol $\mathrm{S}$ Analogues via thyroid hormone receptor $\beta$ : in vitro, in vivo, and molecular dynamics simulation study. Environ Sci Technol 2018;52:6617-25.

49. Zhang YF, Ren XM, Li YY, Yao XF, Li CH, Qin ZF, et al. Bisphenol A alternatives bisphenol $\mathrm{S}$ and bisphenol $\mathrm{F}$ interfere with thyroid hormone signaling pathway in vitro and in vivo. Environ Pollut 2018;237:1072-9.

50. Huang GM, Tian XF, Fang XD, Ji FJ. Waterborne exposure to bisphenol $\mathrm{F}$ causes thyroid endocrine disruption in zebrafish larvae. Chemosphere 2016;147:188-94.

51. Zhang DH, Zhou EX, Yang ZL. Waterborne exposure to BPS causes thyroid endocrine disruption in zebrafish larvae. PLoS One 2017;12:e176927.

52. Naderi M, Wong MY, Gholami F. Developmental exposure of zebrafish (Danio rerio) to bisphenol-S impairs subsequent reproduction potential and hormonal balance in adults. Aquat Toxicol 2014;148:195-203.

53. Aker AM, Ferguson KK, Rosario ZY, Mukherjee B, Alsha- 
wabkeh AN, Calafat AM, et al. A repeated measures study of phenol, paraben and triclocarban urinary biomarkers and circulating maternal hormones during gestation in the Puerto Rico PROTECT cohort. Environ Health 2019;18:28.

54. Aker AM, Johns L, McElrath TF, Cantonwine DE, Mukherjee B, Meeker JD. Associations between maternal phenol and paraben urinary biomarkers and maternal hormones during pregnancy: a repeated measures study. Environ Int 2018;113:341-9.

55. Zhou Z, Zhang J, Jiang F, Xie Y, Zhang X, Jiang L. Higher urinary bisphenol A concentration and excessive iodine intake are associated with nodular goiter and papillary thyroid carcinoma. Biosci Rep 2017;37:BSR20170678.

56. Li L, Ying Y, Zhang C, Wang W, Li Y, Feng Y, et al. Bisphenol A exposure and risk of thyroid nodules in Chinese women: a case-control study. Environ Int 2019;126:321-8.

57. Takagi H, Mitsumori K, Onodera H, Nasu M, Tamura T, Ya- suhara $\mathrm{K}$, et al. Improvement of a two-stage carcinogenesis model to detect modifying effects of endocrine disrupting chemicals on thyroid carcinogenesis in rats. Cancer Lett 2002;178:1-9.

58. Zhang J, Zhang X, Li Y, Zhou Z, Wu C, Liu Z, et al. Low dose of bisphenol A enhance the susceptibility of thyroid carcinoma stimulated by DHPN and iodine excess in F344 rats. Oncotarget 2017;8:69874-87.

59. Zhang Y, Wei F, Zhang J, Hao L, Jiang J, Dang L, et al. Bisphenol A and estrogen induce proliferation of human thyroid tumor cells via an estrogen-receptor-dependent pathway. Arch Biochem Biophys 2017;633:29-39.

60. Pahigian JM, Zuo Y. Occurrence, endocrine-related bioeffects and fate of bisphenol A chemical degradation intermediates and impurities: a review. Chemosphere 2018;207:46980 . 